Sarah Sayce BSc PhD FRICS

is head of the School of

Surveying at Kingston

University, responsible for a

range of RICS-accredited

undergraduate and

postgraduate courses. Vice-

chairman of the Leisure

Property Forum, a new

multidisciplinary organisation

dedicated to promoting

knowledge and understanding

of the industry, Dr Sayce was a specialist assessor for the

British government during its

recent assessment of surveying

education.

Keywords

commercial leisure development, leisure parks, institutional lease requirements, leisure leases, rent review clauses
Dr Sarah Sayce

Head of School,

School of Surveying,

Kingston University,

Knights Park,

Kingston upon Thames, Surrey,

KT1 2OJ London, UK

Tel: +44 (o) 2085477070

Fax: +44 (o) 2085477087

E-mail: s.sayce@kingston.ac.uk

\section{The new leisure leases: Do they measure up to institutional requirements?}

\author{
Sarah Sayce \\ Received 19th June, 2000
}

\begin{abstract}
The acceptability of property for inclusion in institutional portfolios relates to many factors. One is the nature of the lease contract. Over the three decades preceding the 1990s, a lease of 20 to 25 years on full repairing and insuring terms and let at rents which are reviewable upwards only became the accepted institutional 'norm', but research has shown a fragmentation of lease terms emerging during the last decade, reflective partly of recession and partly of changing occupier needs. At the time the institutional lease developed, leisure properties were not generally included in institutional portfolios but remained in operator or specialist ownership. Over recent years, however, new styles of leisure properties have been developed which have begun to enter investment ownership. It is believed that one of the reasons for this lies in the type of leases which leisure operators on the new-style 'leisure parks' have entered into. These are believed to fill the 'norm' in ways possibly less achievable by investors in other types of properties. The paper details some of the characteristics of the newstyle leisure developments and presents findings of a pilot study of some new-style leisure leases. It argues that these do indeed meet investor requirements, although in a way which might present longterm difficulties to the occupying lessees. If this is so, it concludes, the long-term effect for the investor could be negative.
\end{abstract}

\section{INTRODUCTION}

The criteria for institutional acceptability of property has long included that of appropriate lease structures and performance over time. ${ }^{1}$ Indeed, the leasing structure has been regarded as one of the hallmarks of UK property which has been of particular attraction to overseas buyers. ${ }^{2}$ However, as revealed in RICS-sponsored research, ${ }^{3}$ the nature of leasing agreements has changed significantly over the last decade. New leases are often shorter, and the nature of some other covenants has also provided greater diversity. ${ }^{4}$

The RICS study ${ }^{5}$ considered the main investment property types of retail, office and industrial; for the most part it did not address leisure properties because up to the start of 1998 there was too little information included within the Investment Property Databank ${ }^{6}$ to be separately categorised. There were insignificant datasets for 
A different paradigm

New commercial leisure properties inclusion in the study because, until recently, there was little institutional investment in leisure property.

Leisure properties have traditionally not been part of the investorled hegemony that has dominated the UK commercial property markets over the last three decades. They have remained a part of a different paradigm; one based on operator requirements and related to the end user. This tradition of diversity has been manifest in the nature of the properties developed for leisure, the appraisal methodology, ${ }^{7}$ and in a lack of clear land-use policies towards leisure. ${ }^{8}$ However, the advent of 'new-style' leisure developments, notably leisure parks, has provided for the first time a stock of properties aimed at institutional acceptability, both physically and in letting terms. ${ }^{9}$

A number of these commercial leisure properties, notably the leisure parks, have now started to make their way into institutional hands, albeit that, overall, leisure property investment is still principally in the hands of specialist investors ${ }^{10}$ and property companies. ${ }^{11}$ The volume of institutional purchases is insufficient to conclude that an institutional commitment to leisure is now emerging, but the supply of available stock does now, prima facie, appear to satisfy some investment criteria. ${ }^{12}$

This paper defines the new commercial leisure properties and briefly details their characteristics, thus making the case for their orientation to institutional investment ownership. It then investigates the nature of the leases in order to compare them with leases used for other types of commercial property.

In particular the rent review clauses currently in use for prime commercial leisure properties (primarily cinemas, bingo, bowling and FECs - family entertainment centres) are explored to provide some information on the likely relative longer-term performance of leisure-park properties. In doing this the paper aims to provide information which will enable a better understanding of whether the new-style leisure properties do meet institutional requirements. Lastly, the paper discusses the implications of the lease terms revealed on future property management and performance.

\section{A BACKGROUND TO THE NEW COMMERCIAL LEISURE PROPERTIES AND A DEFINITION OF LEISURE PARKS}

The primary objective of this paper is to examine the nature of the lease contracts that are being used for leisure properties. However, to provide a context it is necessary first to define the subject properties and their characteristics in investment terms. For this analysis a number of sources were used ${ }^{13}$ additional information and clarification was obtained by personal enquiry by the author.

Until recently the leisure property sector, if it could even be defined, was primarily occupier driven and often owner occupied. ${ }^{14}$ Where leasing arrangements were found these were generally not geared to institutional owners, and the common perception of a leisure lease was the trade-oriented styles epitomised by public houses. ${ }^{15}$ Trade, too, was the baseline for valuation, with rent 
Leisure parks defined

Integrated developments reviews geared to profitability and turnover. ${ }^{16}$ Analysis was based on the premise of a lack of homogeneity in the physical stock, in value (ie comparable evidence) and in the nature of the tenants, many of whom were small businesses. This was recognised by the RICS in its guidance to valuers. ${ }^{17}$

Although for more than a decade there have been signs that the old relationships were changing, ${ }^{18}$ it was the activity of the property development companies which led to the growth of leisure parks and provided a new style of built stock specifically geared to the investment market. Although leisure parks are by no means the only leisure developments to have taken place, they are worthy of exploration before the leases are examined because they probably constitute the majority of new leisure properties.

Leisure parks are designed to present groups of commercial leisure activities in discrete locations, yet specified physically to allow the development of 'industry norms', and offered on tenurial packages aimed to meet the supposed institutional tests of 'acceptability'.

A widely used definition of a leisure park is 'a purpose built development comprising at least two occupiers and usually anchored by a multiplex cinema. To qualify the park requires a prominent, visible frontage with adequate forecourt style customer car parking. They can be located out-of-town, in fringe locations or town centre sites. ${ }^{19}$ Typically a leisure park occupies a site in excess of ten hectares and is within a 20-minute drive of a minimum population of 200,000.

Although DTZ Debenham Thorpe identify a minimum of two occupiers, parks normally contain 'a range of uses (including cinema, tenpin bowling, bingo and nightclubs, and ancillary facilities such as restaurants and interactive activities), ${ }^{20}$ For this paper they are taken to include both complexes of independent structures and leisure plazas, which comprise single multi-use buildings (for example, Leisureworld, Jarmans Park, Hemel Hempstead).

The parks which comprise ranges of independent structures are often modelled on retail parks, with a single 'anchor' unit designed to meet the particular needs of the tenant and remaining units designed to appeal to any one of a range of uses. Although the widely used definition of a leisure park is but two years old, some of the new leisure developments do not easily fit it. The latest trend is toward more integrated leisure and retail developments both in town and out of town (for example, Trafford Centre, Manchester; Bluewater Park, Kent; and the proposed Arena Central, Birmingham) or integrated leisure schemes in town and city centres (such as Printworks, Manchester).

There are estimated to be close to 90 developments in the UK which meet the definition. Other developments undoubtedly exist which do not fall within the categorisation. Additionally, Knight Frank $^{21}$ conclude that at most there are some 20 still at the preconstruction or planning stage. Given the current planning 


\section{Completion rates}

\section{Accessibility}




\section{A shift in planning policy}

\section{The multiplex 'anchor'}

the appraisal process and ensure the existence of comparable evidence. Over recent years, the keenest investor interest has been in retail premises which appeal to the car-borne consumer (in particular retail warehousing), ${ }^{27}$ although this is now shifting to other sectors, primarily warehouses and business parks. ${ }^{28}$

Leisure developments are frequently associated with adjacent or integral retail schemes, thus implying that the criteria used for retail locations have been applied. Although there appears to be a relationship between the older parks and retail schemes, this is not the case for the trend which emerged in the last decade for 'standalone' schemes. Notwithstanding their new-found 'solus' status, the criteria for their siting is dominated by the view that 'the location criteria of leisure park operators are similar to those for non-food retail warehouse development' and 'is an out of town site with excellent access, ideally on a major junction of an arterial road prominent to passing traffic'. ${ }^{29}$ However, since that statement was made some high-profile in-town schemes (O2 in Finchley Road, London and Printworks, Manchester) are redefining the locational requirements. ${ }^{30}$

One of the factors that could have influenced the divorce, in location terms, between retail and leisure parks has been the recent changes to planning policy. These have effectively put a brake on the siting of retail schemes other than in town-centre locations, due to the introduction of a 'sequential test' ${ }^{31}$ which only allows out-oftown retail schemes if it can be shown that town-centre viability is not threatened. The same braking effect will affect leisure schemes once schemes with extant planning approvals are completed. ${ }^{32}$ Until last year, the evidence was limited. ${ }^{33}$

Despite the dynamics of the planning environment, the locations that have been used for leisure parks do, prima facie, show institutional acceptability, whether they be out of town, edge schemes or in town.

\section{Covenant strength}

One of the major requirements of institutional investors is that all lettings should be to tenants who are unlikely to default on their commitments. They also require assurance that, if a particular tenant were to default, there would be a ready pool of alternative tenants able and willing to take on the commitment. Accordingly, analysis has been carried out to assess the covenants available in the parks. The findings confirm those of DTZ Debenham Thorpe ${ }^{34}$ and Miller Developments ${ }^{35}$ that the anchor users of leisure parks are multiplex cinemas, combined with a variety of food and drink operators and normally with bowling and/or bingo. Other uses include family entertainment centres (FECs), nightclubs and discos and sporting facilities (such as an ice rink or swimming pool). While there has been experimentation in terms of uses represented, potential user types of any leisure park have now reached a point of some standardisation. 


\section{The depth of tenant demand}

\section{Covenant diversity}

\section{The planning categorisation}

However, the standardisation of uses reduces the potential range of operators required to ensure the investment success of any scheme. One of the arguments against investing in leisure was a perceived lack of depth of covenant strength and financial instability of leisure operators. ${ }^{36}$ Occupier analysis relating to the first 50 parks developed reveals that for the major users (cinema, bowling and food and drink) there is limited depth in the potential tenant market of covenants whose standing would be considered to be institutionally acceptable. For example, there are only nine major cinema and bowling covenants; for bingo and health and fitness there are even fewer. ${ }^{37}$ Although the operating 'image' may appear diverse, the number of covenants backing the operations are limited.

The rationalisation within the leisure industry, which has resulted in the growth of large companies which trade across a range of operations, means that any leisure park with, say, ten users could, in reality, have as few as three major covenants backing those uses. The Rank-owned and developed scheme of Leisureworld in Hemel Hempstead enables Rank to trade in one scheme under eight differing operator guises. ${ }^{38}$

Thus, reservations regarding underlying lack of covenant diversity could still suffice to deter institutional investors, given the large lot size (in value terms) that the parks represent, but any notion that leisure property is the sole province of a multiplicity of small independent operators of dubious financial standing appears ill-founded. This shows a new breed of leisure property occupied by multi-outlet national and international concerns which are adept in differentiating their products by brand imaging to give an image of pluralism that denies the reality. The strength of the covenants is without doubt; it is the diversity which could be an issue.

In terms of lease considerations, the quality of the covenant and the ability to secure the continuance of the covenant, even beyond assignment, are issues. ${ }^{39}$

\section{Uses}

Early schemes tended to be built around one key operator (normally a cinema), complemented by food and drink outlets. Later schemes have introduced a wider range of leisure experiences, with a notable increase in health and fitness outlets. The uses within most leisure parks fall within two distinct planning categories. Food and drink outlets are classified in planning terms as retail units, and classified as A3 uses under the Use Classes Order 1987; these are, arguably, not leisure properties at all. ${ }^{40}$ The remainder are leisure users (D2) under the same classification system. The significance of this in value and investment terms is that units which are designated as A3 in use could change to a normal retail use without planning permission; the same is not true for D2 units, which are restricted to leisure use. The use classification may be an issue for the leases, and this is explored later. 


\section{The 'institutional' lease}

\section{Towards institutional ownership}

\section{Tenure}

Institutional investors have a strong preference to own only those properties which are let on standard leases. In this, the UK has developed in a unique way, with long leases, typically of 20 to 25 years' duration, ${ }^{41}$ and with the lessee accepting liability for all repairs and outgoings. Rents have been fixed in relation to comparable transactions and reviewed regularly on an upward-only basis. $^{42}$ The relationship between the nature of the rent review pattern and the protection against falling rents has been held to be an important value-related characteristic.

Prior to the emergence of the new-style leisure developments, the standardisation pattern had not been applied to leisure properties. ${ }^{43}$ In recent years the ability to sustain the standard lease in business space properties has been found to have been at least partially eroded. ${ }^{44}$ Conversely, leisure-park lettings have moved towards the standard long lease. ${ }^{45}$ This appears idiosyncratic, given that the nature of leisure is volatile, and arguably it works against the interests of the occupier. ${ }^{46}$ None the less, the tenure type increasingly established in leisure-park developments is thought to be, at least in terms of lease length, compliant with investor requirements. This is explored via the pilot study.

\section{Leisure-park ownership}

It has been argued that property development companies have a role in interpreting change in society and translating that to property output. ${ }^{47}$ Their aim is to sell on the created product to long-term investors. ${ }^{48}$ To gauge their success, or otherwise, in achieving this ambition for leisure parks, analysis of some 85 leisure parks has been carried out. Table 2 presents the results, which confirm the predominant position exercised by the property companies, extending to nearly 45 per cent of all leisure-park developments. Financial institutions own just over 30 per cent and leisure specialists some 10 per cent. The 'others' category comprises mainly those schemes in which partnerships have been set up (possibly with local authority involvement) to carry out the scheme, and may contain elements of 'social needs' provision. The analysis shows a noticeable shift towards institutional ownership.

Of the five pre-1995 schemes which lie in institutional ownership, four are schemes in which the leisure is integral with a retail scheme, and the last was purchased subsequently from a leisure company. If those leisure-park schemes which are integral with retail are excluded from the analysis, the emergence of institutional investment in leisure parks only started in 1996, a decade after the first scheme was developed. Of the institutional owners, most are insurance companies

The evidence, prima facie, points to property companies having led the sector, with institutional investors prepared to participate based on the premise that their criteria in terms of lease structures and tenant covenant are fulfilled. It would support the view that 
The new leisure leases: Do they measure up to institutional requirements?

Table 2: Summary of ownership classifications of leisure parks

\begin{tabular}{|c|c|c|c|c|c|}
\hline \multirow{2}{*}{$\begin{array}{l}\text { Development } \\
\text { period }\end{array}$} & \multirow{2}{*}{$\begin{array}{c}\text { Number of } \\
\text { schemes }\end{array}$} & \multirow[b]{2}{*}{ Institution } & \multicolumn{2}{|c|}{ Owners } & \multirow[b]{2}{*}{ Other } \\
\hline & & & $\begin{array}{l}\text { Property } \\
\text { company }\end{array}$ & $\begin{array}{l}\text { Leisure } \\
\text { company }\end{array}$ & \\
\hline $1985-1989$ & 16 & 2 & 8 & 3 & 3 \\
\hline $\begin{array}{l}\% \text { of that } \\
\text { period's total } \\
\text { developments }\end{array}$ & & 12.5 & 50 & 18.75 & 18.75 \\
\hline 1990-1994 & 19 & 3 & 7 & 3 & 6 \\
\hline $\begin{array}{l}\% \text { of that } \\
\text { period's total } \\
\text { developments }\end{array}$ & & 16 & 36 & 16 & 32 \\
\hline 1995 onwards & 50 & 23 & 22 & 2 & 3 \\
\hline $\begin{array}{l}\% \text { of that } \\
\text { period's total } \\
\text { developments }\end{array}$ & & 46 & 44 & 4 & 6 \\
\hline Total & 85 & 28 & 37 & 8 & 12 \\
\hline $\begin{array}{l}\% \text { of that } \\
\text { period's total } \\
\text { developments }\end{array}$ & & 32 & 43.5 & 9.5 & 14 \\
\hline
\end{tabular}

Source: Based on DTZ Debenham Thorpe 1997; St Quintin 1997; Breen 1997; Sayce 1998; Hughes 1999.

Leisure parks: gaining in size and number leisure-park development, which Breen identifies as having several phases, ${ }^{49}$ has only been producing schemes which meet full institutional criteria in the last few years.

\section{Summary}

The analysis above points to a rapid increase in the number and size of leisure-park developments. They have presented, for the first time in the UK, cohesive definable groups of buildings which can be 'packaged' to meet the requirements of the institutional owners whose presence has been so influential for retail and office premises. The result has been that, over a period of only three years, the ownership pattern has changed from being predominantly property company and leisure operator led $^{50}$ to one in which institutions are now actively involved. The desire for ownership has been reflected in yields, with transaction yields showing a reduction from almost 10 per cent to a little over 6 per cent, ${ }^{51}$ thus almost in line with other institutional investments. Additionally, DTZ Debenham Thorpe $^{52}$ in their annual survey of investors have revealed a reduction in the risk premia attached to leisure parks, prompting the opinion that this indicates 'strong growth in the leisure sector which may now mean that it [leisure park] fits more comfortably within a typical fund manager's portfolio'.

What now remains is to examine the nature of the lease interface to establish whether this is on true institutional terms.

\section{METHODOLOGY}

There is a dearth of organised published statistics on leisure property. This paper gives the results of an initial, limited 
Leisure leases: data collection investigation of the detail of lease terms, and especially rent review provisions, in the type of leases that have been executed on leisure properties; the aim is to understand the investment interface better.

Data collection took two forms. First, a review of information issued by agents and the property press was analysed, to extend desktop work previously undertaken by the author and by Breen ${ }^{53}$ and Hughes. ${ }^{54}$ Secondly, a questionnaire was circulated to members of the Leisure Property Forum (LPF), an organisation whose membership comprises only those people with both an interest in and knowledge of leisure property. The questionnaire was deliberately kept to two pages to make it possible to complete in about ten minutes by those with the requisite knowledge. No attempt at this stage was made to extend the circulation but, in order to make what would inevitably be a small sample as representative as possible, respondents were asked to complete the form for a lease that was:

- in their personal knowledge; and

- regarded by them as 'typical' of current practice.

As all respondents could be regarded as expert practitioners, the sample is considered to be likely to be more representative of practice than one drawn from a wider cross-section of respondents who had less personal knowledge of and involvement with the commercial leisure market.

The information sought in the pilot study related to the use of the property and its location, and then concentrated on the nature of the lease. Respondents were asked when the lease commenced (pre- or post-1994); 1994 was taken as a watershed, for by this time park developments had reached a point at which a sufficient number had been developed to provide some learning experience on the part of the letting team, and also enabled quick identification of those units for which a review might have been implemented to date.

In terms of the lease document, details were sought relating to the lease length, repairing clause, arrangements for assignments and details of the rent review provisions. Details were also requested in relation to any performance over time, and to any inducements granted at the beginning of the lease. Given that leisure properties normally require extensive fit-out costs, it was anticipated that this could have been an important part of the contractual details.

It is accepted that the construction of the sample had some shortcomings and that the questionnaire would not provide all relevant details necessary for total lease analysis. However, the intention was that this should be a pilot study only, designed to pick up trends and verify — or not - the information that was gleaned from desktop work.

Over a period of two weeks some 31 usable responses were received (approximately 12 per cent response). Additionally some 
Sample data

Most leases post-94 ten letters were received indicating an inability to help but requesting results! Given the limitations of the sampling used, the response was considered satisfactory. In particular, the pilot survey was successful in enabling structured information to be gained which could be analysed in a systematic way.

\section{RESULTS}

\section{The sample properties}

Thirty-one questionnaires were analysed, covering a range of leisure uses and across a geographical distribution. Most (27 or 87 per cent) developments were constructed post-1990; of these 22 (71 per cent) were constructed post-1994. Only two were stated to be refurbished. Consistent with compliance with recent planning guidance, the sample, which was skewed towards the newest stock, was predominantly not out of town: 13 returns (42 per cent) related to in-town properties and 11 ( 35 per cent) to edge of town; only two (6 per cent) were declared to be out of town. The majority of the properties (16 or 52 per cent) were stated to be part of a larger scheme, with only three (10 per cent) being 'solus' developments. The remaining respondents supplied no information.

From this it can be seen that a number of A3 (food and drink) units were included, but easily the greatest grouping was for cinemas. Some of the uses contained within the 'other' categorisation include FECs and health and fitness units. The geographical distribution of the units was slanted towards London and the south-east (18 out of 31 or 58 per cent), perhaps unsurprising given the location of leisure developments, which show a similar orientation.

\section{The sample leases: General provisions}

The findings revealed that 24 (77 per cent) of the leases had been executed post-1994, with five (16 per cent) being prior to that date. There were two non-responses. Examination of the lease terms showed that the modal length of lease was between 21 and 25 years (17 or 54 per cent), with eight ( 25 per cent) being for longer than 25

\begin{tabular}{lccccc} 
Table 3: Types and location of sample properties & & & \\
\hline Type & In town & $\begin{array}{c}\text { Edge of } \\
\text { town }\end{array}$ & Out of town & Not specified & Total \\
\hline $\begin{array}{l}\text { Cinemas } \\
\begin{array}{l}\text { Food and } \\
\text { drink }\end{array}\end{array}$ & 5 & 5 & 1 & 5 & 16 \\
$\begin{array}{l}\text { Bingo } \\
\text { Other D2 } \\
\text { users/mixed }\end{array}$ & 5 & 1 & 0 & 0 & 6 \\
\begin{tabular}{l} 
Total \\
\hline
\end{tabular} & 1 & 1 & 0 & 0 & 2 \\
\hline
\end{tabular}

Source: Pilot survey 
Leases are on full repairing terms

\section{A lack of break clauses}

Capital contributions years and only five (16 per cent) being for 15 years or less. Of these, two related to renewals.

Almost without exception (30 out of 31), leases were let on standard full repairing and insuring terms. The exception related to a letting of part of a building and had an internal repairing clause. In relation to alienation, most allowed both assignment and subletting ( 25 or 81 per cent), but three allowed no sub-letting and one no assignment. The questionnaire then went on to ask, if relevant, whether an authorised guarantee agreement (AGA), as allowed under the Landlord and Tenant (Covenants) Act 1995, was included. Eighteen (58 per cent) of all respondents stated 'yes' and only three (10 per cent) said 'no'. For the remainder, either it was not applicable or the respondent had no information. The extensive use of the AGA arrangements could suggest confidence in the original tenant covenant - or lack of confidence in potential assignees!

The questionnaire also enquired as to break clauses. Perhaps surprisingly, only five respondents (16 per cent) indicated the presence of a break clause, while 25 ( 80 per cent) specified that no break clause was allowed - despite the length of the lease. Further analysis revealed that only two leases contained tenant-operable breaks. In both cases the lease is for longer than 25 years, but for the landlord-operable break-clause leases this is not so; one was contained in a lease of less than 15 years.

The last general area covered by the questionnaire related to the presence (or otherwise) of inducements and rent-free periods. This was considered important, given that most leisure operators have a requirement to continually 'refresh' the brand image of the properties they occupy and the physical finishes have an impact on their ability to trade. ${ }^{55}$ The findings revealed that in 17 cases $(55$ per cent) rent-free periods had been part of the letting deal, and in a further nine ( 29 per cent) there had been capital inducements normally in the form of a contribution to fit-out costs. The importance of the inducements and rent-free periods was most marked for the cinemas (where in one case the contribution was $£ 250,000$ plus a rent-free period), and least in food and drink units.

\section{The sample leases: Rent review provisions}

The questionnaire concentrated on the form of the rent review clause and the basis for valuation at review. The results are set out in Tables 4 and 5.

Where reviews existed, without exception they did not provide for downward as well as upward movement. However, the basis upon which they were reviewable showed much less homogeneity (Table 5).

The findings reveal that only 12 units (38 per cent) specified straight open market rental value (OMRV) as the basis for establishing the rent at review. Of those with a 'formula driver', the most common was to specify the higher of OMRV or 3 per cent per 
The new leisure leases: Do they measure up to institutional requirements?

Table 4: Leisure leases: Rent review period

\begin{tabular}{lccccc}
\hline Annual & Three yearly & Five yearly & None & No response & Total \\
\hline 0 & 1 & 27 & 1 & 2 & 31 \\
\hline
\end{tabular}

Source: Pilot survey

Table 5: Leisure leases: Basis of review

\begin{tabular}{lllllll}
\hline $\begin{array}{l}\text { Open market } \\
\text { rental value } \\
\text { (OMVR) }\end{array}$ & $\begin{array}{l}\text { Retail } \\
\text { price } \\
\text { index }\end{array}$ & $\begin{array}{l}\text { Related to } \\
\text { OMVR, } \\
\text { other use }\end{array}$ & Formula & Turnover & Other & Total \\
\hline 12 & 2 & 5 & 7 & 2 & 3 & 31 \\
\hline
\end{tabular}

Source: Pilot survey

Rent review provisions annum compounded. Similarly, where the retail price index or turnover was quoted, the provision was most commonly placed as an alternative to OMRV - that is to ensure that the lessor obtained the better of two bases. Further analysis (shown in Table 6) between the property types revealed that of the units which had straight OMRV clauses, five related to A3 units, four to cinemas and three to other D2 uses. Thus, five out of six (83 per cent) of the A3 users had OMRV clauses, but only 25 per cent (four out of 16) cinemas and 33 per cent (three out of nine) of the other units had clauses which offered no 'landlord protection' over and above reliance on an OMRV.

Further analysis of rent review clauses with location revealed that a straight OMRV clause was more widely used with properties in London and the south-east. This would support an argument in relation to the volume of properties likely to be available for comparable purposes. There was insufficient information to consider the rent review clause against the size of the scheme and the number of units.

The results of the pilot study present similar findings to those revealed by Hughes ${ }^{56}$ in a survey of institutionally owned schemes, which are analysed in Table 7 . Of these schemes, only one is

\begin{tabular}{|c|c|c|c|c|}
\hline User type & OMRV only & Landlord protected basis & No information & Total \\
\hline A3 users & 5 & 1 & 0 & 6 \\
\hline $\begin{array}{l}\text { D2 } \\
\quad \text { (cinemas) }\end{array}$ & 4 & 11 & 1 & 16 \\
\hline $\begin{array}{c}\text { Other D2 } \\
\text { users }\end{array}$ & 3 & 6 & 0 & 9 \\
\hline Total & 12 & 18 & 1 & 31 \\
\hline
\end{tabular}

Source: Pilot survey 
Table 7: Basis of rent review by scheme

\begin{tabular}{|c|c|c|}
\hline Geographical area & Date of construction & Type of review clause \\
\hline Wales & 1987 & Open market rental value or turnover \\
\hline North-west & 1991 & Tied to retail use \\
\hline North-west & 1996 & Tied to retail or retail warehouse \\
\hline South-east & 1996 & Fixed uplift \\
\hline South-east & 1996 & Minimum fixed uplift \\
\hline Midlands & 1997 & Fixed uplift \\
\hline South-east & 1997 & Tied to retail warehouse \\
\hline South-west & 1997 & Open market rental value \\
\hline South-west & 1998 & $\begin{array}{r}\text { Open market value or } 3 \% \text { minimum } \\
\text { pa compound }\end{array}$ \\
\hline Midlands & 1998 & $\begin{array}{r}\text { Compound increase, some units } \\
\text { fixed uplift }\end{array}$ \\
\hline South-east & 1998 & Mainly minimum uplift \\
\hline South-east & 1998 & Mainly minimum uplift \\
\hline South-east & 1999 & $\begin{array}{r}\text { Open market rental value or } 3 \% \\
\text { minimum pa compound }\end{array}$ \\
\hline North-west & 1999 & $\begin{array}{l}\text { Open market value plus gearing or } \\
\text { fixed increase depending on user }\end{array}$ \\
\hline Total & 14 schemes & $\begin{array}{r}1 \text { open market rental value (OMRV) } \\
8 \text { OMRV plus } 3 \text { tied to other uses } \\
2 \text { fixed increases }\end{array}$ \\
\hline
\end{tabular}

Source: Adapted from Hughes 1999, Appendix A

\section{Added protection to} lessors based on a simple OMRV formula - less than in the pilot survey. In every other case, Hughes found that the lessor has the protection of another mechanism for determining rent in the event that comparable evidence is either not available or provides a result which is unfavourable to the lessor in value terms.

The difference between Hughes's analysis and that of the pilot study is twofold. First, the pilot study was not solely concerned with leisure-park schemes (although most, in the event, were), and secondly the pilot study comprised primarily post-1994 leases. This might indicate that over time there is a gradual shift towards a more open style of lease clause.

Where a basis other than a simple OMRV is used, the arrangement is generally one to protect the lessor - as in almost all cases the use of OMRV is inserted to provide a baseline value. The other provision only 'kicks in' if it results in a figure in excess of OMRV.

The last area examined in relation to the rent review clause was the provision (if any) for third-party dispute. The findings are shown in Table 8.

The choice between the use of independent expert and arbitration as a method of third-party determination depends on several factors, but in general the choice of arbitration over independent expert indicates a confidence in the presence of substantial levels of evidence, sufficient to argue a case at a hearing or by written representation. The choice of independent expert is more common where such confidence does not exist. The findings here show a preference towards arbitration - although it should be 
The new leisure leases: Do they measure up to institutional requirements?

\begin{tabular}{lccccc} 
Table 8: Leisure leases: Third-party dispute provisions & & \\
\hline User & $\begin{array}{c}\text { Independent } \\
\text { expert }\end{array}$ & Arbitration & Either & $\begin{array}{c}\text { None/ } \\
\text { don't know }\end{array}$ & Total \\
\hline A3 & 0 & 3 & 3 & 0 & 6 \\
D2 & 3 & 6 & 1 & 6 & 16 \\
$\quad$ (cinemas) & 3 & 3 & 1 & 2 & 9 \\
D2 (other) & 6 & 12 & 5 & 8 & 31 \\
Total & & & & &
\end{tabular}

Source: Pilot survey

\section{A lack of rent reviews to date}

\section{'Ratchet rents'}

borne in mind that the use of formula provisions to provide a 'floor' might reduce the number of third-party instructions.

\section{Rental value information}

The primary purpose of the investigation was to try and provide some information on lease terms. However, the opportunity was taken to ask questions about rental performance at review where applicable. As the majority of leases were granted post-1994 and with five-yearly rent review clauses, it proved to be too early an exercise to obtain useful information. In the event, information was given in relation to two of the A3 units and two cinemas. All were reviewed in 1998. A simple pattern of value increase did not exist. Increases ranged from zero over three years for one of the A3 units to close to 10 per cent per annum for one of the cinemas, with the other registering the minimum 3 per cent per annum uplift.

\section{Summary}

The findings indicate that, at least for the sample examined, the new leisure leases are formatted in ways which satisfy the traditional definition of institutional acceptability - at least as far as the lease length and repairing clauses are concerned. The issue of covenant strength, identified earlier, has perhaps influenced the nature of the rent review provisions, which, for the most part, contain some form of additional protection for the landlord. This additional protection takes various forms, but the most commonly occurring in the sample was the use of a minimum uplift - usually 3 per cent per annum compound. Sometimes this was only for the first one or two review periods, but in several cases it stretched right through the 25-year term. If a comparison is undertaken between leisure leases and the lettings achieved for other types of commercial property, some reasons for institutional interest become clear. Accordingly, set out below is a comparison of the leisure leases as revealed in the pilot study with those shown to prevail in the remainder of the UK markets by the extensive literature survey carried out by Crosby and Murdoch ${ }^{57}$ and that using IPD data by Crosby and Lizieri. ${ }^{58}$ 


\section{ANALYSIS IN COMPARISON TO OTHER COMMERCIAL LEASE PRACTICE}

Long-term arrangements

Protecting privity

\section{Lease length}

Crosby and Murdoch ${ }^{59}$ found that between the years 1990 and 1995 the average lease length of commercial property fell from some 23.4 years where there was no break clause and 23.0 years with a break clause, to 14.7 years without a break clause and 13.8 years with one. This contrasts with the situation of the 1970s and 1980s when 25 years had become standard, and was given as one of the major reasons for the inflow of overseas funds to the UK property investment market.

In terms of lease length, the findings suggest that leisure leases are likely to be attractive to investors seeking long-term investments. The significant length of the lease is, however, only of comfort to the lessor if there is confidence that the lessee will remain solvent over the period. If the lessee defaults then the lease length is of little practical comfort. Hence the lease length must be viewed as part of the whole package of lease terms.

\section{Covenant strength and the privity question}

Covenant strength may not be an issue given reasonable market conditions and a favourable lease structure, but in a recession it becomes of crucial concern to investment values. ${ }^{60}$ Indeed, it was the issue of covenant strength and the ability of a landlord to claim on an original tenant following assignment which gave rise to controversy $^{61}$ and legislative change in England. ${ }^{62}$

In response to the change in the law, Crosby and Murdoch ${ }^{63}$ concluded that it was 'too soon to be at all certain of the long-term effects of the 1995 Act', although they viewed the evidence as suggesting that the use of AGAs was 'fast becoming the universal practice'. Analysis of the leisure lease assignment clauses reveals that the use of AGAs is very widespread, possibly because initial covenants are strong, but limited in terms of potential numbers of good assignees. It is therefore not surprising that the sample shows little variation from the general practice noted by other surveys. ${ }^{64}$ However, the reality is that if one cinema or bingo operator is unable to sustain profitability there may well be a very limited pool of potential assignees, and even a good original tenant may sometimes default on a lease, leaving the lessor in a strongly adversely prejudiced position. ${ }^{65}$

\section{Break clauses}

The pilot study revealed that very few break clauses had been included in the sample leases. This could be regarded as surprising on two counts:

- it differs from the practice in other commercial leases as revealed by Crosby and Lizieri, ${ }^{66}$ although they admitted that 
Onus on the lessee

\section{Strong letting environment}

even on their analysis of all properties contained within the IPD index 'it was difficult to judge due to possible data constraints and the lack of distinction between new leases and renewals'; and

- the lessees of the leisure properties are effectively tied into potentially very onerous leases for periods which far outreach their usual business horizon; given the essentially fast-moving nature of commercial leisure provision - as demonstrated by the rapid change in specification of the required leisure units - and the comments above in relation to the depth of covenants, this would appear to be a very real potential problem for lessees.

The explanation of the quantum of use of break clauses in business space leases was attributed by Crosby and Murdoch ${ }^{67}$ to negotiating strength in the market. If they are right, then the sample of leisure leases examined would support evidence of a strong letting environment.

\section{Repair and maintenance}

The standard arrangement which has arisen as part of the institutional lease requirements has been that the cost of repairing and maintaining the demised property falls on the lessee directly in the case of single-unit letting and effectively via a service charge provision in the case of multi-let properties. Albeit that this practice is at variance with the practice in virtually all other countries, ${ }^{68}$ the latest survey revealed no evidence to suggest that, in relation to prime property, this approach changed during the recession.

The evidence from the pilot survey confirms that for leisure properties the same regime prevails, with only one response relating to a unit let on other than full repairing and insuring terms. This is perhaps not surprising, given that many leisure operators need to 'refresh' their image over very short time spans and thus require, operationally, complete physical control.

What the survey did not reveal, and which could usefully be ascertained by more detailed work, is the arrangements for service charges and sinking funds given that most units are multi-let schemes - whether these be one covered unit or an open park. The very nature of leisure development places an emphasis on the aesthetic appeal and visual impact, thus, it is argued, for operational success the necessity exists for common parts to be maintained to a high standard.

\section{Inducements and rent-free periods}

Crosby and Murdoch ${ }^{69}$ identified the increased practice over the recession of the early 1990s of a high incidence of granting inducements to persuade lessees to enter leases. Among these the most common were rent-free periods for fitting out, unspecified rent-free periods, capital payments and staggered rents. The more detailed analysis by Crosby and Lizieri $^{70}$ reveals that the incidence 


\section{Rent-free periods}

Prescence of rent protection clauses of rent-free periods declined as the commercial property market moved out of recession, but that a relationship did exist between the age and location of the property. They found that average overall levels of rent-free periods did not exceed 40 per cent even in the depth of the recession, ${ }^{71}$ although these findings have been held to be suspect. ${ }^{72}$ Clearly the sample of leisure leases examined was too small to draw detailed conclusions, but the level of incidence of rent-free periods or other inducements, at over 90 per cent, was higher than for commercial properties generally.

The question that this raises - but does not answer - is whether rent-free periods and capital contributions are structurally part of the commercial leisure letting market. If 'traditional' leisure lettings are recalled, ${ }^{73}$ then the inference would be that they are. That would imply an issue for interpretation at the time that rent reviews are settled. ${ }^{74}$

\section{Rent reviews}

The litigation surrounding the settlements of rent reviews has been extensive, as almost any text on landlord and tenant law will substantiate. ${ }^{75}$ However, although the intricacies of the settlement of disputes covers the full range of period of review, machinery for implementation, basis of valuation at review and disputes procedure, the chief area of concern to investors is the basis upon which the rent is reviewed and the presence (or otherwise) of an upward-only review.

In the case of the survey of leased property within the IPD portfolio, ${ }^{76}$ the actual basis of the review was not considered to be an issue - other than the prevailing use of upward-only clauses. The implicit assumption was that all reviews would be to OMRV, with the passing rent acting as a 'floor' beneath which the rent could not fall.

There was no indication of landlords being routinely able to build in increases based on either the retail price index or a prescribed minimum uplift. However, the presence of a 'simple' OMRV clause among the leisure sample, other than the A3 units, was rare - with two-thirds of the true leisure units providing the landlord with an alternative method of assessment in the event that OMRV did not outperform projected levels of inflation or cost increases.

This could be regarded as:

- a reaction because of the relative immaturity of the market;

- a measure to protect the lessor against a possible paucity of comparable evidence on which to form on opinion of OMRV;

- a consequence of a paucity of lettings; ${ }^{77}$

- indicative of a strong letting market in which the landlord can effectively dictate terms.

Whatever the reason for the proven ability of lessors to impose such potentially punitive review clauses, the result would appear to 


\section{Main features of the leisure lease}

be the creation of an investment vehicle which provides an almost unique bond and equity style of investment - provided the covenant is strong enough to withstand any changes over the duration of the lease. Given that some of the sample leases are in excess of 25 years, this represents a heavy risk to the lessee.

\section{IMPLICATIONS}

The findings point to the new leisure leases broadly 'fitting the mould' of other commercial properties, with three major differences:

- they are more homogeneous in lease length, and in many cases longer than the leases which have been available for other commercial properties, particularly offices;

- they are more likely to have inducements or lessor contributions written into the original letting;

- in many cases they have additional protection to the lessor at rent review, with the majority of D2 users containing either reference back to retail use or, more commonly, with minimum uplift provisions that are likely to outstrip inflation in the foreseeable future.

The implications for investors are clear. Leisure leases, superficially at least, provide a rationale for investment. At worst they will receive rents that go up in line with or just ahead of inflation; at best real rental growth, linked to continued growth in consumer spending on leisure, will provide a justification for the yields currently being achieved. Not only that, but the covenants, many of which are secured by a few large parent concerns (such as Rank, Bass and Whitbread), are protected by authorised guarantee agreements included as part of the lease documentation. If real rental growth does occur, the position of the investor lessor is much the same as for any other type of commercial property except for two factors: information on investment performance and covenant diversity.

The level of future rental growth and overall performance is always an unknown, despite the development of forecasting and modelling techniques. However, in the case of most commercial properties there is a long run of property datasets upon which projections can be based. For leisure properties no such long-run datasets exist to provide investor comfort. Even where long runs do occur, there are problems surrounding valuation and calculation of capital value where the rent review provisions are non-standard. ${ }^{78}$ With these new commercial leisure properties such difficulties are inherent.

If underlying economic trends are the issue then there is a comfort in leisure. ${ }^{79}$ However, if property investment decisions were made in relation to economic criteria alone, leisure would have been a preferred investment sector for many years. So the investing 


\section{Restricted number of covenants}

\section{Non 'user friendly' leases}

\section{Attraction to institutional investors}

lessor is still not in the same position as the owner of other commercial space.

In terms of covenant diversity, analysis has pointed to leisure covenants being strong in quality but restricted in number. This is perhaps not an issue for the A3 uses, but for cinemas and other D2 uses there is a potential long-term problem - if an anchor tenant simply cannot sustain a unit over the 25 -year period, there may be a lack of potential assignees - and the rent review clauses revealed in the pilot study will require the operators not merely to sustain the rents at today's level, but to increase levels over time. Given the projections for inflation and the recent slowdown in cinema attendances, ${ }^{80}$ this may well be a future issue. But if there is an issue for the lessors, the same must be true but more so for the lessees.

The survey reveals that the leases are less 'user friendly' than many others granted at the same time for other business uses. Yet the property formats are not proven over time, and the speed with which design is changing may render obsolete units constructed only five or ten years previously. Indeed, the consideration of the definition of leisure parks revealed that definitions accepted only two years ago may now require rewriting. Against such rapid change and the consequent risk of premature obsolescence, the lessees appear completely unprotected - except in so far as the leases may enable them to change brand and image. The implications of this could be that leisure property lessees face a worse scenario than that of many office tenants during the early 1990s when 'over-renting' occurred, ${ }^{81}$ for over-renting will occur unless leisure rents not only do not fall back but actually increase above the rate of projected inflation year on year.

The nature of leisure leases, as revealed by the pilot study, supports anecdotal information that the new leisure developments offer lessors perhaps the best available opportunity to buy into traditional institutional lease terms. However, what is at issue is the long-term performance, given the rapid changes in operational demands. If the decade of the 1990s has held any lessons for commercial property owners it is the need to develop a more occupier-focused approach. ${ }^{82}$ The 25 -year lease with its framework built on a hands-off style of property management may appear inappropriate if landlord and tenant are both taken to be risk sharers in property investment. The new leisure leases are constructed on a premise of the lessee accepting the burden of risk in relation to long-term performance. Yet if that risk proves too much over time, it will be lessors via the process of default and rising yields who stand to share the loss.

\section{CONCLUSIONS}

The rise of the leisure parks has been fast. Just a decade ago, there were only five that met the definition. Now there are close to 20 times that number. The initial growth was in edge-of-town and out-of- 
Insititutional conformity

\section{Comparison with retail warehouse}

\section{Attractive lease structures}

town, but changes to planning policy have restricted further locations developments in such locations. The result has been a shift towards in town. There has also been a rapid shift in the design style, from early 'solus' schemes and sheds to the integrated 'urban entertainment centres', perhaps epitomised by $\mathrm{O} 2$ in Finchley Road.

One of the features of leisure parks is the attempts by their creators to meet some measures of conformity. In terms of their lease terms, their notion of 'tenant mix' and their locational requirements, they are designed to comply with investor requirements. They are physically specified so that they can accommodate a variety of leisure uses. The more they appear to be like retail units, the more likely it is that they will succeed in attracting investment funds. From starting as an operator-driven phenomenon in which the instigator sought to capitalise on social trends towards eating out and cinema attendance, they have developed into apparently repetitious formuladriven developments. They may display outward signs of individuality; inwardly and tenurially they are predictable.

The leisure-parks analyses reveal that property companies have been influential in the development of a 'leisure property product' which, superficially, appears to meet the criteria established both by literature and empirical evidence for institutional investment. Indeed, the creation of the leisure-park 'product' would support claims that 'in many respects the current leisure park investment market is reminiscent of the retail warehouse sector as it was in the early 1980 s. $^{83}$ There is now much evidence that institutions are prepared to invest in such schemes, albeit that it is still in the nature of an 'acquired taste'. But the question is whether their interest relates to the inability of other stock to offer the lease interface that they have traditionally required, a positive desire to invest in leisure, or the particular attraction offered by the type of lease that operators of leisure schemes have signed.

In terms of leisure-park property it is suggested that the attraction to institutions lies in the lease structures. The analysis of lease terms in the pilot study would support this, although a largerscale survey is required for verification. Of the leases analysed, lease length and covenants fit the required model. However, the real key would appear to relate to the rent review terms. At first sight it appears that there is a real 'buying in' to leisure, with many leases having so-called OMVR clauses. However, a closer examination shows that most of the sample D2 units have clauses which are 'copper-bottomed' to ensure that a rental increase is received - the most common being a minimum of 3 per cent per annum compounding. Given the projected rates of inflation, this looks less like a commitment to leisure than a means of investing in property in a way which hedges it against index-linked gilts.

Of the properties that had straight OMVR clauses, the majority were either A3, which some would regard as not leisure in use, or central London properties, arguably a special market. For the rest, the landlord appeared to have needed the security of a protection 


\section{Moves to conformist modernism}

\section{Away from plurality}

\section{Inflexible and rigid} frameworks against possible non-performance, and the guarantee clauses introduced are surely a concern to the operators.

The ambition of the property development companies to provide an institutional vehicle has been largely fulfilled. None the less, in developing these properties, the property companies have changed the relationship which previously marked out leisure properties. Traditionally associated with operator ownership, leisure properties were developed by those who were the interpreters of social trends. They have not sat within a paradigm of conformist modernism which has been the hallmark of commercial property over the last half century. Instead, leisure properties were remarkable for their pluralism and diversity. What has been novel about the development of leisure parks is that they have been developed to fit models of conformity. As society has moved towards pluralism they have moved counterwise.

In conclusion, the leisure parks are founded on an assumption that the growth of leisure as an economic good will justify the establishment of a rigid long-term relationship to be appropriate. There is, however, a danger that, by trying to capture in the inflexible conformist tenurial patterns, the best covenants on which to predicate returns, an anomaly has been created. The moves to conformity now mean that tenants who face the need to respond to changes in leisure trends are, in many cases, 'locked in' to their legal agreements for up to, or even beyond, 25 years.

An inflexible and rigid framework to an investment based on a need for continuing flexibility of image and location has been created. It remains to be seen whether the relationships are sustainable. With social and demographic patterns changing rapidly and instability in the work/leisure relationship, the very notion of unchanging occupational requirements for leisure property may be as virtual a reality as that played out within the new leisure-park structures.

\section{References}

1. McIntosh, A. P. J. and Sykes, S. G. (1985) A Guide to Institutional Property Investment, London: Macmillan; Stapleton, T. (1994) Estate Management Practice, (2nd ed.) London: UK Estates Gazette; Rydin, Y., Rodney, W. and Orr, C. (1990) 'Why do institutions invest in property?', Journal of Property Finance, Vol. 1, No. 2, pp. 250-258 Scarrett, D. (1995) Property Asset Management, (2nd ed.) London: E\&FN Spon; Isaac, D. (1998) Property Investment, Basingstoke: Macmillan.

2. Johnson, R. (1992) A Global Real Estate Strategy - Which Way for Growth?, Reading: College of Estate Management.

3. Lizieri, C., Crosby, N., Gibson, V., Murdoch, S. and Ward, C. (1997) Right Space, Right Price? A Study of the Impact of Changing Business Patterns on the Property Market, London: RICS.

4. Crosby, N. and Lizieri, C. (1998) Changing Lease Structures - An Analysis of IPD Data Paper 5 of the Right Space, Right Price Research Report, London: RICS.

5. Lizieri et al., ref. 3 above.

6. Investment Property Databank (1998) IPD Annual Index, London: IPD.

7. Sayce, S. (1995) 'Leisure property: A profitable concern', in De Leeuw, A. and Sayce, S. (Eds) Theorie und Praxis der Wertermittlung und Gebauden, Grund und Boden, Frankfurt: Peter Lang. 
8. Ravenscroft, N. (1992) Recreation Planning and Development, Basingstoke: Macmillan; Sayce, S. (1992) 'Leisure property and the impact of leisure land use planning in the UK', paper presented to the Conference on Instruments for the Protection and Rational Use of Land, European Faculty of Land Use and Development, Strasbourg, June; Rydin, Y. (1998) Urban and Environmental Planning in the UK, Basingstoke: Macmillan; Leisure Property Forum (1998) 'Planning and legal aspects: PPG6 and leisure', Leisure Property Forum Newsletter, No. 5, pp. 4-5.

9. Sayce, S. (1998) 'An examination of the potential of leisure property as an institutional investment vehicle', unpublished $\mathrm{PhD}$ thesis, University of Reading.

10. Leadbetter, S. (1998) 'The attraction of leisure: An investor's view', talk to the Leisure Property Forum meeting, 25th June.

11. DTZ Debenham Thorpe (1997) UK Leisure Parks Report, London: UK Estates Gazette; St Quintin (1997) A Review of Leisure Park Development in the UK, London: St Quintin.

12. Sayce, ref. 9 above.

13. DTZ Debenham Thorpe, ref. 11 above; St Quintin, ref. 11 above; Breen, P. (1997) 'The commercial leisure park sector and the institutional investor: A marriage made in hell?', unpublished dissertation, Kingston University; Sayce, ref. 9 above; Hughes, P. (1999) 'Institutional interest in leisure investment: Covenant strength?', unpublished dissertation, Kingston University.

14. Ravenscroft, ref. 8 above; Sayce, ref. 9 above.

15. See for example, Gilham, B. (1993) 'How should pubs be valued?', Journal of Property Valuation and Investment, Vol. 11, pp. 217-224.

16. Marshall, H. and Williamson, H. (Eds) (1996) Law and Valuation of Leisure Property, (2nd ed.) London: Estates Gazette.

17. Royal Institution of Chartered Surveyors (1995) The Valuation and Appraisal Manual, RICS, GN7.

18. For example, Erdman Lewis (1993) Evolution not Revolution, London: Erdman Lewis.

19. DTZ Debenham Thorpe, ref. 11 above, p. 1.

20. St Quintin, ref. 11 above, p. 6.

21. Knight Frank (1999) Leisure Property Review, Spring, London: Knight Frank.

22. London Planning Advisory Committee and London Transport Planning (1998) Leisure Development in London, London: Planning Advisory Committee and London Transport Planning.

23. St Quintin, ref. 11 above.

24. Breen, ref. 13 above, p. 56.

25. See for example, Scott, P. (1996) The Property Masters, London: E\&FN Spon.

26. It is outside the scope of this paper to debate institutional criteria for property investment. This has been explored in a range of literature - for example McIntosh, A P. J. and Sykes, S. G. (1985) ref. 1 above; Rydin et al., ref. 1 above; Hargitay, S. and Yu, M.-H. (1993) Property Investment Decisions, London: E\&FN Spon; Ball, M., Lizieri, C. and Macgregor, B. (1998) The Economics of Commercial Real Estate, London: Routledge; Isaac, ref. 1 above.

27. DTZ Debenham Thorpe (1996) Money into Property, London: DTZ Debenham Thorpe.

28. DTZ Debenham Thorpe (1999) Money into Property, London: DTZ Debenham Thorpe.

29. St Quintin, ref. 11 above, p. 24.

30. Welch, J. (1999) 'Rise of a two-tier market?', Property Week Leisure Supplement, June. p. 6.

31. Planning Policy Guidance notes (PPGs), issued from time to time by central government, have had an increasing effect on the development process. In particular PPG6 (out-of-town retail) and PPG13 (transport) have combined to operate against future out-of-town retail schemes. Their relationship with leisure developments is less clear.

32. Kitson, T. (1997) 'Planning permissions and other consents', paper presented to the Henry Stewart Conference on Leisure Property; Stephens, S. (1997) 'Report threatens future of out-of-town schemes', Leisure Week, 21st March.

33. Recent decisions now confirm that leisure parks will be treated in a similar way to retail schemes - see Leisure Property Forum, ref. 8 above. 
34. DTZ Debenham Thorpe (1995) Invest in Leisure, London: DTZ Debenham Thorpe, p. 4.

35. Miller Developments (1996) A Survey of Commercial Leisure Development, Edinburgh: Miller Developments.

36. Thame, D. (1995) 'Leisure special report - Boxing clever', Property Week, 3rd August, p. 41.

37. Sayce, ref. 9 above.

38. See the case study in Breen, ref. 13 above; St Quintin, ref. 11 above, p. 9.

39. Prior to 1995 under English law an assignor remained liable to the landlord under the doctrine of privity of contract. The Landlord and Tenant (Covenants) Act 1995 effectively ended this rule. However, the right within the Act to allow landlords to impose, on the grant of a lease, conditions in relation on assignment, including the imposition of an authorised guarantee agreement (AGA) reduces the effect of the Act by providing limited assurance for the landlord.

40. Sayce, ref. 9 above.

41. Crosby, N. and Murdoch, S. (1998) Changing Lease Structures and Commercial Property Markets, Paper 2 of the Right Space, Right Price Research Report, London: RICS.

42. See for example, Isaac, ref. 1 above.

43. Marshall and Williamson, ref. 16 above.

44. Lizieri et al., ref. 3 above.

45. Breen, ref. 13 above.

46. Leadbetter, ref. 10 above.

47. Healey, P. (1992) 'An institutional model of the development process', Journal of Property Research, Vol. 9, pp. 33-44; Byrne, P. (1996) Risk, Uncertainty and Decisionmaking in Property Development, (2nd ed.) London: E\&FN Spon.

48. Nabarro, R. (1990) 'The investment market in commercial and industrial development: Some recent trends', in Healey, P. and Nabarro, R. (Eds) Land and Property Development in a Changing Context, Aldershot: Gower.

49. Breen, ref. 13 above, p. 5.

50. Sayce, ref. 9 above.

51. Knight Frank (1998) Leisure Property Review, Summer, London: Knight Frank; Welch, ref. 30 above.

52. DTZ Debenham Thorpe, ref. 28 above, p. 10.

53. Breen, ref. 13 above.

54. Hughes, ref. 13 above.

55. Marshall and Williamson, ref. 16 above.

56. Hughes, ref. 13 above.

57. Crosby and Murdoch, ref. 41 above.

58. Crosby and Lizieri, ref. 4 above.

59. Crosby and Murdoch, ref. 41 above, p. 8.

60. See for example, Crosby, N. and Goodchild, R. (1992) 'Reversionary freeholds: Problems with over-renting', Journal of Property Valuation and Investment, Vol. 11, pp. 67-81; Crosby, N. and Murdoch, S. (1994) 'Capital valuation implications of rent free periods', Journal of Property Valuation and Investment, Vol. 12, pp. 51-66.

61. Hillson, S. (1995) 'The Landlord and Tenants (Covenants) Bill', Journal of Rent Review and Lease Renewal, Vol. 15, pp. 12-20.

62. The Landlord and Tenant (Covenants) Act 1995.

63. Crosby and Murdoch, ref. 41 above, pp. 14-15.

64. For a review of these, see Crosby and Murdoch, ref. 41 above.

65. See for example, the case of Co-operative Insurance Society v Argyll Stores (Holdings) Ltd, 199609 EG 128, which illustrates that even a strong lessee covenant is insufficient adequately to protect a landlord against changes in market conditions.

66. Crosby and Lizieri, ref. 4 above, p. 23. 
67. Crosby and Murdoch, ref. 41 above

68. For example, Dubben, N. and Sayce, S. (1991) Property Portfolio Management: An Introduction, London: Routledge; Johnson, ref. 2 above; Crosby and Murdoch, ref. 41 above.

69. Crosby and Murdoch, ref. 41 above, p. 16.

70. Crosby and Lizieri, ref. 4 above.

71. Ibid., p. 17.

72. Lizieri et al., ref. 3 above, p. 19.

73. As per Marshall and Williamson, ref. 16 above.

74. See for example, Hillson, S. (1998) 'Rent review developments', Journal of Rent Review and Lease Renewal, Vol. 18, pp. 247-252.

75. See for example, Smith, P. F. (1989) The Law of Landlord and Tenant, London: Butterworth; (5th ed) (1993) Hill and Redman's Law of Landlord and Tenant. London: Butterworth; Bernstein, R. and Reynolds, K. (1995) Essentials of Rent Review, London: Sweet and Maxwell; Pawlowski, M. (1995) Casebook on Landlord and Tenant Law, London: Sweet and Maxwell.

76. Crosby and Lizieri, ref. 4 above.

77. See for example, Sewell, R. (1998) 'Hypothetical review clauses for high bay warehouses - The pitfalls', Journal of Rent Review and Lease Renewal, Vol. 18, pp. 137-139.

78. For example, McAllister, P. (1996) 'A note on the analysis of stepped rents', Journal of Rent Review and Lease Renewal, Vol. 16, No. 2, pp. 16-20.

79. See McIntosh, A. P. J. (1998) 'Trends in leisure investment', Leisure Property Forum, London, 25th June.

80. Knight Frank, ref. 21 above

81. Crosby, N. and Goodchild, R. (1993) 'Reversionary freeholds: Problems with overrenting', Journal of Property Investment and Finance, Vol. 11, No.1.

82. Edington, G. (1997) Property Management: A Customer-Focused Approach, London: Macmillan; Weatherhead, M. (1997) Real Estate in Corporate Strategy, London: Macmillan

83. St Quintin, ref. 11 above, p. 38. 